\title{
Potential of Douglas-fir as a partial substitute for Norway spruce - review of the newest Czech literature
}

\author{
Vilém Podrázský
}

Department of Silviculture, Faculty of Forestry and Wood Sciences, Czech University of Life Sciences Prague, Kamýcká 1176, 16521 Praha 6-Suchdol, Czech Republic, E-mail:podrazsky@fld.czu.cz

Abstract: Podrázský Vilém, 2015: Potential of Douglas-fir as a partial substitute for Norway spruce - review of the newest Czech literature. - Beskydy, 8 (1): 55-58

Presentation summarizes the results concerning the effects of cultivation of Douglas-fir (Pseudotsuga menziesii /Mirb./ Franco), especially in the last decades, on the intensity of production as well as non-production forest functions in the conditions of the Czech Republic. It analyzes the research outcomes from the point of view of volume and value production in comparison with other native tree species, from the point of view of the soil effects and effects on the ground vegetation diversity, and from point of view of stability and cultivation in the last period. Main aim is represented by the comparison with the Norway spruce, which can be with advantages replaced by this species, with favourable impact on amount and value of the timber production, on the soil and biodiversity status of the ground vegetation. Also the stability of forest stands can be supported considerably. Douglas-fir represents favourable alternative to the Norway spruce in lower and middle altitudes and it can contribute highly to the competitiveness of the Czech forestry.

Key words: Douglas-fir, production, soil effects, biodiversity effects, Norway spruce substitution

\section{Introduction}

Douglas-fir (Pseudotsuga menziesii /Mirb./ Franco) represents an exotic (introduced) tree species with the highest production potential among those from the temperate vegetation zone worldwide. In many countries, it represents large plantations with high economic importance (France, Germany), reaching hundreds of thousands of ha. In the Czech Republic, there are cca 5,800 ha of Douglas-fir plantations, increasing by some hundreds ha each year (Kubeček et al. 2014, Vašíček 2014). On the other side, Norway spruce (Picea abies /L./ Karst.), as the most important native species, has many problems connected with climate extremes (climate change), manifesting as large-area spruce decline. Partial replacing of Norway spruce by Douglas-fir is so desirable at lower altitudes and on locations with lower precipitations (Podrázský et al. 2014a, 2014b). Relatively detailed research started in Europe reflecting importance of Douglas-fir in the future in many countries of the Western and Central Europe. Aim of the presented paper is completely document the production and environmental effects of this species basing especially on original studies in the conditions of the Czech Republic.

For successful introduction, the selection of a proper provenance is necessary. For W-Europe, the Douglas-fir provenances from the coastal zone of the North American Pacific region seem to be the best, for Central Europe, more interior provenances are suitable. In other European countries, the populations originating from more continental climate could be suitable (Beran 1995, Petkova et al. 2014, Popov 2014). In many regions, the selected populations are available, because this species is planted for more than one century and the local conditions selected the most adapted genotypes, disposable both for natural as for artificial regeneration. 


\section{Production of the Douglas-fir}

Many reports and studies documented the superiority of the Douglas-fir to other species growing in comparable conditions. On specific sites, only Grand fir can compete this species (Fulín et al. 2013). In majority of other sites studied, Douglas-fir (DF) did show the highest growth and production (Kubeček et al. 2014). On the other side, there are still many methodological problems. E.g. Petráš and Mecko (2008) modeled the production based of yield tables and site indexes. They document the results showing lower volume as well as value production of the Douglas-fir comparing to silver fir and Norway spruce (by 26-35\%) or even beech (22\%). Reason for these results is considerable lower density of Douglas-fir stands at the same stand heights comparing to other species. But, on the contrary, this approach fails for the simple fact, that on the same site, the Douglas-fir reaches highly bigger height and diameter growth comparing to other species (Kantor 2008, Kantor, Mareš 2009, Kantor et al. 2001a, 2001 b, Remeš et al. 2010).

Studying individual tree growth and production, opposite extreme is observed. For example, Kantor et al. (2001a, 2001 b) documented a dominant production role of the Douglas-fir in the stands of middle age (age 68 years, mixed stands - Scots pine, European larch, oak, beech, hornbeam, lime tree). In the given age, the volume of individual Douglas-fir trees reached up to $2.9 \mathrm{~m}^{3}$, supposing even $6 \mathrm{~m}^{3}$ at the age 100 years. Authors recommend 10-30 \% Douglas-fir admixture.

Similarly, Kantor (2008) evaluated the Douglas-fir production at more rich, i.e. mesotrophic sites of the Krrtiny Training Forest Enterprise (MENDELU Brno) in mature stands. There were 29 mixed stands surveyed in total, with considerable share of Douglas-fir at an age of 85 to 136 years. In each stand, 10 largest Douglas-firs with the 10 largest Norway spruces or European larches were compared as for height, DBH and standing volume. Significantly higher production potential of introduced Douglas-fir was found in all assessed stands. There were registered tree groups where the volume of Douglas-fir was 2 to 3 times higher than the volume of spruce or larch. For example, the mean volume for 10 tallest trees in one particular stand was recorded as $9.12 \mathrm{~m}^{3}$ for Douglas-fir, $3.17 \mathrm{~m}^{3}$ for spruce and $3.70 \mathrm{~m}^{3}$ for larch. Annual ring analyses have shown that at present the volume increment of particular Douglas-fir trees ranges from 0.12 to $0.16 \mathrm{~m}^{3} \cdot \mathrm{yr}^{-1}$ in these mature stands (i.e. about $1.5 \mathrm{~m}^{3}$ during the last 10 years).

This team (Kantor, Mareš 2009) continued also with the study of Douglas-fir production potential at acid sites of the Hůrky School Forest (Písek, South Bohemia), using the same methodology. In total, 17 mixed stands with the presence of Douglas-fir aged 88 to 121 years were assessed. Comparing 10 Douglas-fir trees with 10 Norway spruce, Scots pine or European larch trees of the largest volume, higher and generally markedly higher production potential of the introduced Douglas-fir was always found in all assessed stands again, in similar extend as in the previous case. In one of the measured stands, the mean volume of the 10 largest Douglas-fir trees was $6.30 \mathrm{~m}^{3}$, comparing to only $1.93 \mathrm{~m}^{3}$ for spruce and $2.25 \mathrm{~m}^{3}$ for larch. The volume increment determined on the base of particular Douglas-fir tree ring analyses ranged between 0.06 to $0.10 \mathrm{~m}^{3} \cdot \mathrm{year}^{-1}$.

Pulkrab et al. (2014) modelled the economic effects of the Douglas-fir cultivation in the range of the whole Czech Republic. They used the possibilities, given by the Czech legislation and Forest Management Plans recommendations. They concluded, that there is a potential for Douglas-fir cultivation on 149,616 to 163,713 ha (today 5,800 ha), representing 5.7 to $6.2 \%$ of the stand area (today totaling $0.22 \%$ ). The potential value increment ranged so between 25-28 mil. EUR per year for the whole Czech Republic. Replacing of the Norway spruce in lower altitudes by Douglas-fir seems to be very realistic and effective from the economical point of view.

\section{Soil effects of Douglas-fir}

Similarly, our original as well as other studies confirmed soil improvement (or neutral) effects of the Douglas-fir in broader European conditions (Augusto et al. 2003, Kubeček et al. 2014), always positive in comparison with the Norway spruce. In the more detailed case studies, Kupka et al. (2013) and Ulbrichová et al. (2014) evaluated the effects of Douglas-fir and Norway spruce on the soil characteristics and humus accumulation in middle altitudes $(410 \mathrm{~m})$ and middle aged (cca 50 years as well as mature stands (99 years) in the Kostelec n. Černými lesy area. For both species, soil characteristics describing acidity, sorption complex, quantitative characteristics of humus profile and amount of total and accessible nutrients were compared. The holorganic horizons acidity was significantly lower by $(-0.75 \mathrm{pH})$ as well as exchangeable $\mathrm{H}^{+}$and $\mathrm{Al}^{3+}$ ions content (two times lower) in 
Douglas-fir stand compared with spruce stands. More favorable conditions of qualitative soil sorption complex characteristics were also confirmed in Douglas-fir stand, with significantly higher base saturation and total base content (both two times higher values). Accessible nutrients content in the upper organic horizon differed significantly for calcium and magnesium (in all organic horizons), and also for potassium and phosphorus in the upper organic horizons, with higher content in Douglas-fir stands again. Total nutrients content differed only in the case of calcium with higher values in Douglas-fir stand. In the study area, positive effect of Douglas fir on the soil characteristics compared with Norway spruce was fully confirmed. Comparing to other domestic coniferous tree species, Douglas-fir acidifies less the upper soil layers and contributes to development of more favorable humus forms. It recycles nutrients more effectively and produces litter which is easily decomposed and transformed. It could be considered as an appropriate partial substitution for Norway spruce in corresponding site conditions. Very similar results were obtained by Menšík et al. (2009).

\section{Plant communities effects of Douglas-fir}

The biodiversity aspect is also vitally important. To this moment, only the Douglas-fir effects on the ground vegetation were studied. The most recent study is represented by Podrázský et al. (2014 b). In total, 67 parallel plots were chosen from the database of 153 phytosociological relevés made in the Douglas-fir and parallel Norway spruce, European beech and oaks dominated stands to find influences of this introduced tree on the understory layer in totally 12 localities on the whole Czech Republic territory. Douglas-fir stands influence their habitats, which was indicated by species composition changes in the ground vegetation, as well as by abundance and dominance of particular species. Douglas-fir cultivation increases species diversity of the stands, but decrease their abundance. Described differences in understory are not so noticeable, when European beech and sessile oak stands are substituted by Douglas-fir once. But even the significant phenomenon of striking nitrophilous species occurrence as Geranium robertianum, Urtica dioica and Galium aparine manifests here. This indicates conspicuous content of available nitrates in the humus and top of the soil horizon.

\section{Conclusions}

Douglas-fir represents very promising tree species from the point of view of perspective introduction. There are relatively high production effects, the timber of this species being of good quality, comparable to Norway spruce or European larch (Remeš, Zeidler 2014). Its share in the stand structure should represent cca $20-40 \%$ of the individuals, regularly distributed. In this case, the production potential of the forest stands should increase considerably, with visible effects related to higher stability of the stands, improved humus as well as soil status, comparing to other coniferous species. Also the biodiversity of the ground vegetation will be affected less negatively, comparing to more common conifers such as Norway spruce, Scots pine or European larch. There is clear and positive potential of this species, to partly replace the Norway spruce in lower altitudes, where this species suffers because of climate change and/or extremes.

\section{Acknowledgement}

This paper was supported by a project NAZV QJ1520299: Applying Douglas fir in forest management of the Czech Republic

\section{References}

Augusto, L., Dupouey, J-L., Ranger, J. 2003: Effects of tree species on understory vegetation and environmental conditions in temperate forests. Annals of Forest Science, 60: 823-831.

Beran, F. 1995: Dosavadní výsledky provenienčního výzkumu douglasky tisolisté v ČR [Up-to-date results of the provenance research of the Douglas fir]. Zprávy lesnického výzkuти, 40 (3-4): 7-13.

Fulín M., Remeš J., Tauchman P. 2013: Růst a produkce jedle obrovské (Abies grandis Lindl.) ve srovnání s jinými jehličnany [Growth and production of the grand fir (Abies grandis Lindl.) in comparison with other conifers]. Zprávy lesnického výzkumu, 58 (2): 186-192.

KANTOR, P. 2008: Production potential of Douglas fir at mesotrophic sites of Kr̈tiny Training Forest Enterprise, Journal of Forest Science, 54 (7): 321-332.

Kantor, P., Mareš, R. 2009: Production potential of Douglas fir in acid sites of Hůrky Training Forest District, Secondary Forestry School in Písek, Journal of Forest Science, 55 (7): 312-322. 
Kantor, P., Knott, R. , Martiník, A. 2001a: Production capacity of Douglas fir (Pseudotsuga menziesii [Mirb.] Franco) in a mixed stand. Ekológia (Bratislava), 20 (Suppl. 1): 5-14.

Kantor, P., Knott, R., Martiní, A. 2001 b: Production potential and ecological stability of mixed forest stands in uplands-III. A single tree mixed stand with Douglas fir on a eutrophic site of the Krrtiny Training Forest Enterprise. Journal of Forest Science, 47: 45-59.

Kubeček, J., Štefančík, I., PodrázskÝ, V., LonGAUER, R. 2014: Výsledky výzkumu douglasky tisolisté (Pseudotsuga menziesii /Mirb./ Franco) v České republice a na Slovensku přehled. [Results of the research of Douglas-fir in the Czech Republic and Slovakia - review]. Lesnicky časopis - Forestry Journal, 60 (2): 120-129.

KupKa, I., PodrÁzsKÝ, V., KubeČeK, J. 2013: Soil-forming effect of Douglas fir at lower altitudes. Journal of Forest Research, 59 (9): 345-351.

Menšír, L., Kulhavý, J., Kantor, P., Remeš, M. 2009: Humus conditions of stands with the different proportion of Douglas fir in training forest district Hůrky and the Křtiny Forest Training Enterprise. Journal of Forest Sciences, 55: 345-356.

Petkova, K., Goergieva, M., Uzunov, M. 2014: Investigation of Douglas-fir provenance test in North-Western Bulgaria at the age of 24 years. Journal of Forest Science, 60 (7): 288-296.

Petráš, R., Mecko, J.2008: Rastovýa produkčný potenciál douglasky na Slovensku [Growth and production potential of Douglas fir in Slovakia] In: Pěstování nepuivodních dřevin. Kroméríž 26. 6.2008. ČLS, Kroměříž, s. 59-64.

PodrÁZskÝ, V., Zahradník, D., Remeš, J. 2014a: Potential consequences of tree species and age structure changes of forests in the Czech Republic - review of forest inventory data. Wood Research, 59 (3): 483-490.

Podrázský, V., Martiník, A., MatěJKa, K., Viewegh, J. 2014 b: Effects of Douglas-fir (Pseudotsuga menziesii [Mirb.] Franco) on understorey layer species diversity in managed forests. Journal of Forest Science, 60 (7): 263-271.

Popov, E.B. 2014: Results of 20 years old Douglas-fir provenance experiment established on the northern slopes of Rila Mountain in Bulgaria. Journal of Forest Science, 60 (9): 394-399.

Pulkrab, K., Sloup, M., Zeman, M. 2014: Economic Impact of Douglas-fir (Pseudotsuga menziesii [Mirb.] Franco) production in the Czech Republic. Journal of Forest Science, 60 (7): 297-306.
Remeš, J., Zeidler, A. 2014: Production potential and wood quality of Douglas fir from selected sites in the Czech Republic. Wood Research, 59 (3): 509-520.

Remeš, J., Pulkrab, K., Tauchman, P., 2010: Production and economical potential of Douglas fir on selected locality of the School Training Forest Kostelec nad Černými lesy. /In Czech/. In: News in silviculture of introduced tree species. CULS Prague, Kostelec n. Č. l., p. 68-69.

Ulbrichová, I., Kupka, I., Podrázský, V., KubeČek, J., Fulín, M. 2014: Douglaska jako meliorační a zpevňující dřevina. [Douglas-fir as site improving and stabilizing tree species] Zprávy lesnického výzkumu, 59 (1): 72-78.

VAšǏČEK, J. 2014: Data o douglasce tisolisté v ČR. [Data on Douglas-fir in the CR]. Lesnická práce, 93 (7): 17. 